\title{
What is the Relationship between the Four Dimensions of the Balanced Scorecard and Organization Performance of Ghanaian Public Universities?
}

\author{
Remy Nyukorong, $\mathrm{DBA} / \mathrm{PhD}$
}

Stichting Kongregatie FIC, The Netherlands

Doi:10.19044/esj.2022.v18n1p20

Submitted: 03 October 2021

Accepted: 27 January 2022

Published: 31 January 2022
Copyright 2022 Author(s)

Under Creative Commons BY-NC-ND

4.0 OPEN ACCESS

Cite As:

Nyukorong R. (2022). What is the Relationship between the Four Dimensions of the Balanced Scorecard and Organization Performance of Ghanaian Public Universities?. European Scientific Journal, ESJ, 18 (1), 20. https://doi.org/10.19044/esj.2022.v18n1p20

\begin{abstract}
The Balanced Scorecard (BSC) is one of the best-known strategic planning and evaluation tools that uses both monetary and non-monetary data. This paper focuses on empirically testing whether the four dimensions of the BSC predicts organizational performance of Ghanaian public universities. The study adopted a cross-sectional, descriptive survey design and the primary sources of data was gathered through hand-administered structured questionnaires from both academic and administrative staff of 10 accredited public universities in Ghana. The study also employed structural Equation Model (SEM) with SmartPLS to analyze 134 samples. Results of the boostrapping method for the structural model and the t-values of the four dimensions of the BSC were significantly and statistically different from each other, but all showed a positive relation on perceived organizational performance. The results showed that non-financial measures have better outcomes for employees' performances which corroborates the central proposition of the Balanced Scorecard. It is recommended that public universities that want to maintain and improve organizational performance must pay attention to the customers' perspective by providing relevant and high-quality education that acquaints students with knowledge and transferable basic skills and also identify opportunities for special initiatives, collaborative partnerships, and accountability to constituents.
\end{abstract}


Keywords: Balanced Scorecard, public universities in Ghana, strategic management system

\section{Introduction \\ Global Demands on Higher Education Institutions}

For several years now, both private and public universities have been competing in the international market. This is particularly seen in universities that operate within the framework of neoliberal, market-oriented reform policies. They believe that competition is the only valid and authentic norm for all human activity (Bleiklie, 2001; Deem et al., 2008; Fadeeva \& Mochizuki, 2010; Storey, 2002). On the other hand, some universities are identified by their decentralised decision-making approach, democratisation of access to tertiary education, and operation within budget constraints (Bleiklie, 2001; Smeenk et al., 2008).

Despite this, universities' stakeholders (i.e., the state, alumni, prospective students, and other external constituencies), demand their increased responsibility, quality improvement, and accountability which is relative to their productivity, efficiency, and usefulness (Billing, 2004; Smeenk et al., 2008; Stewart \& Carpenter-Hubin, 2000). Therefore, universities formulate policies, rules, and regulations (PRRs), benchmarks, and quality controls to evaluate their performance since they are increasingly and more frequently customer-driven and market-controlled (Billing, 2004).

Today, more than ever, the society has become increasingly convoluted, and universities are confronted with myriad challenges of managing continuous change to remain relevant (Caruth \& Caruth, 2013). Universities are striving always to effect changes in policies to transition from the prevailing circumstances to the future one, which requires new management forms towards greater flexibility, agility, and effectiveness regarding responsiveness to societal demands (Aktas, 2015; Lawrence \& McCullough, 2001). Public universities globally are therefore required to keep on innovating and improving their institutional structures and processes in order to tackle the shifting challenges constantly knocking at their doors and to simultaneously take advantage of the myriad opportunities before them.

The new perspective regarding universities as critical building blocks in the socioeconomic life of states is based on the principles of open science or open scholarship (Ayris et al., 2018). This includes the delivery of inclusive, evenly balanced access to quality learning and the dissemination of high impact scientific research project (Arnesen \& Lundahl, 2006). Institutions that adopt a cultural change towards open scholarship could grow, expand, and interact with the opportunities and challenges in the environment where they are active participants (Ayris et al., 2018; European Commission, 2018). 
These strings of change drivers have intensified in post-World War II era and organizations have increasingly become complex but also with corresponding complexity in the production and management processes. This has put pressure on many organizations as they are determined to cope with the challenges. Consequently, in the 1980s, many corporate leaders adopted new management models and tools, such as Total Quality Management (TQM), the Kaizen job method training (Imai, 1986), structuration theory (Pettigrew, 1990), business process re-engineering and others (Pearce, 2003), to aid them perform more efficiently. This also serves as a means to effectively control human behaviour.

In view of the above, several universities in the developed and developing worlds have adapted or are making the effort to adapt to the changing circumstances as they re-structure their institutions and give priority to the improvement of their institutional performance and accountability (Fijatkowska \& Oliveira, 2018). Such advances have unavoidably resulted in the development of bureaucratic or businesslike processes and methods (Jauhiainen et al., 2015). The extant literature even suggest that many public universities have started using the business language to create plans, formulate strategic goals, and apply performance management principles to put institutional resources to effective use (Billing, 2004; Smeenk et al., 2008). In the past, Welch (2007) observed that universities and other higher institutions of learning were implementing new forms of governance, managerial styles, and principles that were widespread and dominant in the corporate business segment. The reasoning behind these novel administrative reforms was to increase universities' value for money or price-performance ratio (Deem, 1998; Waring, 2013). Hence, the financing of universities is an essential component within a regulated and ineffectually free market economy (Marginson, 2013).

\section{Managerial Innovations Within Public Organisations}

In the place of the Progressive Public Administration (PPA) accountability model, the New Public Management (NPM) has emerged. NPM embraced a different understanding of public accountability. Also, it adopted different models of trust and distrust, which resulted to a different kind of "accountingization" (Hood, 1995, p.93). The main reason for this new management concept is to reduce or eliminate the differences that exist between the public and the private sector. Thus, this shifts the weight from process accountability towards a greater aspect of accountability in terms of the end-product. Accounting is an essential component in this modern understanding of accountability. Accountability here reflects high trust in the market and private business practices and low trust in professionals and public servants. 
The NPM is a two-level concept. First, it is a general theory that the public sector can be improved by the importation of business concepts, techniques, and values. Second, and in ordinary usage, NPM is a bundle of specific concepts and practices which includes greater stress on performance that specifically occurs through the measurement of outputs; a preference for (i.e., lean, flat, small, specialized) organizational structures over large, multifunctional structures; a widespread substitution of contracts for hierarchical relations as the principal coordinating device; a widespread injection of market-type mechanisms, including competitive tendering, public sector league tables, and performance-related pay; an emphasis on treating end-users as 'customers' and on the use of generic quality improvement methods such as Total Quality Management (TQM). The discussions of this section and the previous one is summarized in Table 1.

Table 1. Three waves of reform thinking

\begin{tabular}{|l|l|}
\hline Period & Characteristics of Dominant Discourse \\
\hline $\begin{array}{l}\text { Mid-1960s to } \\
\text { late 1970s }\end{array}$ & $\begin{array}{l}\text { Rational, hierarchical planning and cost-benefit analysis. Science and } \\
\text { expertise will produce progress. }\end{array}$ \\
\hline $\begin{array}{l}\text { Late 1970s to } \\
\text { late 1990s }\end{array}$ & $\begin{array}{l}\text { New Public Management. Business techniques to improve efficiency. } \\
\text { Rise of 'better management as the solution to a wide range of problems. }\end{array}$ \\
\hline $\begin{array}{l}\text { Late 1990s- } \\
\text { present }\end{array}$ & $\begin{array}{l}\text { No dominant model. Several key concepts, including governance, } \\
\text { networks, partnerships, 'joining up', transparency, and trust. }\end{array}$ \\
\hline
\end{tabular}

\section{The State of Accredited Public Universities in Ghana}

In the last two decades, traditional universities in Ghana have faced several challenges such as frequent changes of legal regulations and education laws, persistent pressures and demands for greater quality, reduced public funding, and increased competition from private and foreign universities. On the other hand, traditional public universities across Ghana are facing the challenges of restructuring and reforming themselves so that they deliver quality education and nurture students who will become productive members of their communities. Public universities in Ghana are also expected to conduct research and provide consultative services so that they address the urgent multifaceted problems of Ghana and transform the nation.

Furthermore, student admissions and enrolments in Ghanaian universities is on the increase recently. Conversely, this puts pressure on the resources of universities and poses a great challenge to institutional performance concerning effective teaching and learning due to the level of autonomy with which universities and other tertiary institutions operate (Ofori \& Atiogbe, 2012). Despite the presence of oversight and supervisory institutions, such as the National Council for Tertiary Education (NCTE) and the National Accreditation Board (NAB) which have been set up and mandated to effectively supervise and make the activities of higher institutions 
of learning more efficient, the quality of graduates produced by universities remains a serious concern for many stakeholders.

For instance, the NCTE cites weakening quality in service delivery as one of the main challenges facing Ghanaian public universities. This appalling trend is attributed to the high student/staff ratios and proliferation of private universities and university colleges in the country (National Council for Tertiary Education, 2018). Thus, there is the need to evaluate the prevailing strategic performance management practices of accredited public universities in Ghana from a multifaceted perspective such as the Balanced Scorecard.

Past studies have found that the performance measurement systems are particularly important in higher education settings. Therefore, to measure the performance, Al-Zwyalif (2012) indicated that the universities should implement the Balanced Scorecard to manage and assess the overall performance. The orderly methodology leads to clear guidance for employees in the organization to accomplish the annual targets. Balanced Scorecard is an innovative measurement tool in appraising the performance of an organization. It is commonly recognised among organizational level since it was initiated in the early 1990s. Subsequently, BSC provides a comprehensive equilibrium between the short-term and long-term plan, monetary and nonmonetary parts, internal and external process, and company's advantage and consumer's advantage (Kassahun, 2010). The BSC also allows the top management to ensure that the strategy is coherent with the mission, vision, and objective of the organization.

Empirical research shows that "only 5 percent of the workforce understands their company strategy, 25 percent of managers have incentives linked to strategy, 60 percent of organizations do not link budgets to strategy, and 86 percent of executive teams spend less than one hour per month discussing strategy" (Balanced Scorecard Collaborative, 2002, p.2). To improve such avoidable failure of executing a strategic plan, professionals suggest setting up a new way of communicating strategy to the final consumer by implementing the Balanced Scorecard (BSC) model. With BSC, strategy gets to every employee in a language that makes sense (Kassahun, 2010).

The Balanced Scorecard puts vision and strategic goals at the centre and not control. This is then translated into a performance measurement system and is sequentially reflected in responsiveness and overall strategic orientation. The Balanced Scorecard is appropriate to the type of design many companies are trying to become. It sets goals but assume that every employee or member of staff of the organization will adopt whatever actions and behaviours are required to attain organizational goals (Camilleri \& Camilleri, 2018; del Sordo et al., 2012; Fijatkowska \& Oliveira, 2018). Hence, the performance system of the Balanced Scorecard is not envisioned for performance measurement only but also for the purposes of effectively 
planning, implementing, monitoring, supervising, and evaluating the entire organization. It is an integrated system that is also in line with the ongoing creativities in many organizations.

By bringing together the financial and non-financial assessments (i.e., financial, internal process \& innovation, organizational learning and growth, and customer viewpoints), the leaders of organizations are able to tacitly understand several interconnections. This insight can support leaders and managers to rise above traditional ideas concerning operational obstacles and eventually bring about better quality in problem-solving and effective decision making. The Balanced Scorecard keeps organizations continuously looking and moving into the future rather than looking back (Kaplan \& Norton, 1992).

The next section of this article is devoted to the discussion of relevant literature reviews on the nature of the performance management frameworks and the use of the Balanced Scorecard as a performance measurement tool. A separate section describes the elements of the research design and methodology including the selection of study participants and research instruments. This is then followed by the results and interpretation and discussion of the data analysis. The final sections discussed the limitations and provided future research possibilities.

\section{Performance Management Systems}

Andre de Waal (2006) defined performance management systems as "the formal, information-based routines and procedures which managers use to maintain or alter patterns in organizational activities". This definition was adapted from Simons (2000). Performance management systems (PMS) usually revolve around communicating financial and non-financial data that have an impact on decision-making and organizational practices.

Today, more than ever before, organizations and institutions are increasingly implementing a performance management system to realize better organizational outcomes in a dynamic environment that is constantly changing (Bititci et al., 2004; Davis \& Albright, 2004; Eccles, 1991; Epstein et al., 2004; Marr, 2004). Despite these positive and constructive benefits of performance management systems, several organizations have difficulties and challenges implementing one (Franco \& Bourne, 2003). According to Simons (2000), a performance management system cannot be successfully planned and implemented without considering human behaviour. Therefore, Holloway and Colleagues (1995) observed that the effective implementation of a performance management system largely depends on accepting and accommodating the behavioural elements of performance management. de Waal (2006) strongly reinforced this important view.

The universities evaluative systems may include an analysis of the respective universities stated intentions, peer opinions, government norms and 
comparison, and primary procedures from self-evaluation through external peer review. These metrics can be drawn from published indicators and ratings among other frameworks (Billing, 2004). According to Cappiello and Pedrini (2017), universities performance evaluations can be either internally or externally driven. The internally driven appraisal systems put more emphasis on self-evaluation and self-regulatory activities (Baxter, 2017). On the other hand, the externally driven evaluative frameworks may involve appraisal interviews that assess the quality of the employees' performance in relation to pre-established criteria. Public universities ought to continuously re-examine their strategic priorities and initiatives. It is in their interest to regularly analyze their performance management frameworks through financial and nonfinancial indicators and assess the productivity of their human resources as well. Therefore, they should regularly review educational programs and course curricula (Brewer \& Brewer, 2010). On a faculty level, the university leaders ought to keep a track record of changes in the size of departments, age and distribution of academic employees, diversity of students and staff in terms of gender and ethnicity, et cetera. In addition, faculties could examine discipline-specific rankings and determine the expenditures per academic member of staff among other options (Camilleri \& Camilleri, 2018).

\section{The Stakeholder Theory}

Stakeholder theory is fundamentally a business and management concept. Freeman, Harrison, and Zyglidopoulos (2018) discussed the basic concepts and application of stakeholder notions in addition to the benefits this concept brings to organizations and their management teams. The qualities, power, urgency, and legitimacy of claims characterize the stakeholders of an organization (M'maiti, 2014). Both power and urgency must be paid attention to if executives and leaders are to serve the moral and legal interests of rightful stakeholders of the organization (Mitchell et al, 1997). Therefore, stakeholder theory encompasses processes and procedures that recognize and oversee the interests of stakeholders.

Furthermore, a large volume of work has been performed on categorizing the relative impact of various stakeholders (Mitchell et al, 1997). To be able to distinguish stakeholders from non-stakeholders, M'maiti (2014) advised managers to have a clear idea of what exactly a stakeholder connotes. Freeman $(1984$, p.46) has defined the concept as ".... any group or individual who can affect or is affected by the organization's objectives." This definition is still frequently quoted, and it gives a broad meaning and understanding of the concept. It is also like Thompson's (1967) understanding of a stakeholder, which means "those groups which make a difference." Based on the theory that has been provided, it can be assumed that public universities and higher education institutions can be branded as being complex environments with 
manifold stakeholders or participants that frequently hold multiple, distant, and somehow conflicting goals. Nevertheless, there have been no significant evidence from the literature that strongly stops the transfer of operational philosophies, methods, and principles from the business world to the public domain.

Notwithstanding, the possibility of fruitful consequences of such transfers is presumed to have a connection with the level of behavioural modification to fit the descriptions and qualities of the target context. The Balanced Scorecard acts in two ways. First, it is developed to fit the requirements of the 'citizen sector'. Second, it complements the special needs of the government sector or public domain (Bridoux \& Stoelhorst, 2016; Harrison et al., 2019). Though slightly distinct in content and structure, the underlying principle (or logic) for operating either form is the need to improve and achieve a strategy that is more focused on higher metrics than purely financial metrics.

Besides the focus of the Balanced Scorecard on financial elements, it also specifies a foundation for defining other valuable factors that shape how an establishment can function and achieve its vision. Stakeholder theory comprises of a multiplicity of management capacities and methods that are mainly created to support managers working in complex surroundings (Harrison et al., 2019). Core principles of the theory involve accepting that any arrangement or establishment is contained and bounded by a multiple stakeholder and these stakeholders (customers) can greatly influence the establishment of the organization. It is thus imperative to have a sound comprehension of the interests of significant stakeholders to remodel an organization or an establishment with least conflict (Bridoux \& Stoelhorst, 2016; Harrison \& Wicks, 2013). Stakeholder analysis is mostly constructive in mapping strategic shareholders (stakeholders) of an organization as well as discovering their needs in the organization. The stakeholder analysis therefore appears to be an appropriate solution therapy for the complexity interrelated challenges of the Balanced Scorecard as a critical tool for performance management.

\section{The Balanced Scorecard}

According to several academics (Brancato, 1995; Deming, 1993; Ruben, 1999; Williams \& Ceci, 1997), the fundamental mission of public universities and their academic departments and programmes is the advancement of excellence in the creation, sharing, and application of knowledge. This is usually described in terms of teaching, scholarship (research), and public service (community outreach). Fulfilling this mission requires a distinguished faculty, high-level research activities, innovative and engaging teaching-learning processes, supporting technology and quality 
facilities, capable students, competent faculty and staff, and legislative and public support. Although historically less well appreciated, it also requires excellence in communication and a service-oriented culture, appropriate visibility, prominence within the state and beyond, a welcoming physical environment, a friendly, supportive and respective social environment, accessible and effective systems and services, and a sense of community.

Specifically, the fulfilment of this mission requires successful engagement with several constituency groups. More so, the desired and potentially measurable outcome can be identified for each group such as the prospective students, current students, faculty, staff, families, alumni, employers, colleagues at other institutions, governing boards, local community, friends, interested individuals, donors and benefactors, legislators, and the public. The Balanced Scorecard approach offers an institution the opportunity to formulate a cascade of measures in order to translate the mission of knowledge creation, sharing, and utilization into a comprehensive, coherent, communicable, and mobilizing framework for external stakeholders and for one another.

The Balanced Scorecard is a performance management framework, i.e., an integrated results-oriented measurement tool, which incorporates the financial and non-financial elements that relate the vision, mission, and core beliefs of the organization with initiatives, strategies, and specific targets that are intended to produce continuous performance improvements (Beard, 2009; Cullen et al., 2003; Kaplan \& Norton, 1992; Taylor \& Baines, 2012; Umashankar \& Dutta, 2007; Wu et al., 2011). The four-performance metrics of the Balanced Scorecard play a critical role in converting the strategies of the organization into actionable activities. Thus, the Balanced Scorecard can be employed to evaluate the performance of public universities. The tool presents a balanced performance management approach as it includes several performance indicators that can evaluate various perspectives of an organization (Taylor \& Baines, 2012). According to the Balanced Scorecard approach, the financial dimensionality is a fundamental performance measure. On the other hand, the remaining three aspects, i.e., internal process, organizational capacity, and customer (in particular, students \& other stakeholders) perspective, should be considered in the performance evaluations of public universities in Ghana as explained in Table 2 below.

In addition, the performance targets of many universities and other higher education institutions involve the following elements: the research impact of universities, the completion rates of students, establishment of collaborative alliances with business and the labour market, inter alia. These are critical performance indicators that are frequently and extensively being used in global competitive standard practices such as the European Quality Improvement System (EQUIS). 
Table 2. The Balanced Scorecard Approach in Public Universities

\begin{tabular}{|c|c|c|}
\hline Perspective & Question & Explanation \\
\hline $\begin{array}{lr}\text { Financial } \\
\text { This } \\
\text { considers perspective } \\
\text { university's productive } \\
\text { resources and financial } \\
\text { performance. }\end{array}$ & $\begin{array}{l}\text { How can public } \\
\text { universities improve } \\
\text { their financial } \\
\text { performance? } \\
\text { How can they use the } \\
\text { scarce financial } \\
\text { resources in an } \\
\text { efficient and effective } \\
\text { way? }\end{array}$ & $\begin{array}{l}\text { This perspective covers traditional } \\
\text { measures including sales revenue } \\
\text { (fees charged for services, etc.), } \\
\text { research grants, costs and expenses, } \\
\text { profitability, and return on } \\
\text { investment. }\end{array}$ \\
\hline $\begin{array}{l}\text { Internal Business } \\
\text { processes } \\
\text { This involves faculty } \\
\text { members as well as the } \\
\text { administrative staff of } \\
\text { the university. }\end{array}$ & $\begin{array}{l}\text { What are the } \\
\text { universities internal } \\
\text { processes that can } \\
\text { enhance } \\
\text { educational goals and } \\
\text { objectives? }\end{array}$ & $\begin{array}{l}\text { This perspective considers the } \\
\text { internal processes and operations. } \\
\text { This includes examining the delivery } \\
\text { of student-centred quality education, } \\
\text { scientific research output of faculty } \\
\text { members, and collaboration } \\
\text { partnerships with trade and } \\
\text { professional bodies. This perspective } \\
\text { also considers the internal resources, } \\
\text { services, and facilities that are } \\
\text { utilized by personnel in internal } \\
\text { operations. }\end{array}$ \\
\hline $\begin{array}{l}\text { Organizational } \\
\text { Capacity } \\
\text { This } \\
\text { innovation, concerns } \\
\text { learning, life-long } \\
\text { professional continuous } \\
\text { development } \\
\text { academic and non- } \\
\text { academic employees, } \\
\text { and investing in skills } \\
\text { development. }\end{array}$ & $\begin{array}{l}\text { How can public } \\
\text { universities improve } \\
\text { their organizational } \\
\text { learning to create } \\
\text { value for students, the } \\
\text { university, } \\
\text { themselves, and the } \\
\text { society as a whole? }\end{array}$ & $\begin{array}{l}\text { This dimension takes into } \\
\text { consideration the institutional } \\
\text { performance through the lenses of } \\
\text { human capital, technology, } \\
\text { infrastructure, cultural and other } \\
\text { capacities that are fundamental and } \\
\text { critical towards creation and } \\
\text { dissemination of knowledge. It } \\
\text { considers the universities research } \\
\text { quality and output, the capacity to } \\
\text { maintain a competitive advantage } \\
\text { through the identification of training } \\
\text { needs of faculty members, } \\
\text { administrative staff, and other } \\
\text { members of the university. }\end{array}$ \\
\hline $\begin{array}{l}\text { Customer focus } \\
\text { This includes students, } \\
\text { parents, alumni, policy } \\
\text { makers in education, and } \\
\text { publics. }\end{array}$ & $\begin{array}{l}\text { What do public } \\
\text { universities customers } \\
\text { (stakeholders) need } \\
\text { and desire? }\end{array}$ & $\begin{array}{l}\text { This dimension considers } \\
\text { organization performance from the } \\
\text { perspective of its customers } \\
\text { (students/other stakeholders). It } \\
\text { focuses on the provision of courses to } \\
\text { students and employed individuals } \\
\text { who are furthering their education. It } \\
\text { includes outreach and collaborative } \\
\text { partnership agreements with external } \\
\text { bodies such as government, business, } \\
\text { and industry. }\end{array}$ \\
\hline
\end{tabular}


Furthermore, the Balanced Scorecard can be utilized to evaluate the commitment of faculty members towards their employer (McKenzie \& Schweitzer, 2001; Umashankar \& Dutta, 2007). Despite this, Wu et al. (2011) maintained that the organizational capacity perspective of the Balanced Scorecard is associated with the employee learning, innovation, and growth. Therefore, the dimension of the universities' intangible resources as well as their intellectual assets are influenced by other dimensions, particularly the financial perspective (Taylor \& Baines, 2012).

\section{Balanced Scorecard and Organizational Performance}

This study has considered the benefits of the Balanced Scorecard as a performance management system. It was observed that organizations which implemented this new management system obtained unlimited innovations in all aspects of the organization, particularly within the management team (Kaplan \& Norton, 2001). This experience is the same with first time adopters who accomplished remarkable results within a relatively short time (i.e., within 12 to 24 months) when they employed the Balanced Scorecard on the organizational strategy map. Lucianetti (2010) found that the formation of strategy maps influences the effectiveness of Balanced Scorecard framework with reference to perceived benefits. It is also a fact that organizations' accomplishments cannot be attributed to new service provision or a new project financing but rather to the organization's maturity and process development. This is achieved through a performance management system that results from the implementation of the Balanced Scorecard (Kaplan et al., 2001). It is the Balanced Scorecard that combines the tangible assets with intangible assets in value-creating activities. For strategy-focused organizations, strategy implementation is probably the most critical success factor influencing corporate valuations and managerial actions.

Therefore, organisations and institutions could gain a lot from the Balanced Scorecard if they formulate strategy maps and combine that with appropriate behaviours and attitudes (Lucianetti, 2010; de Waal, 2004). The notion of organizational performance is greatly linked to strategy execution through the Balanced Scorecard. Figge, Hahn, and others (2002) have explained non-financial initiatives as critical effective factors that enrich organizational performance by deliberately linking sustainability to core strategy (Nathan, 2010).

Other factors cited as valuable factors for optimum resource allocation include planning, budgeting, and formal curriculum implementation. As Farid and Mirfakhredini (2008) have argued, the financial ingredients produce actual results in financial deliverables to enhance organizational performance. Some of these financial elements include fund raising, revenue from operations, and sound financial management. The financial perspective as an 
operational management issue is therefore necessary so as to accomplish the goals and objectives of the organization (Saunders et al., 2008).

Barnes (2007) attested that Balanced Scorecard was implemented in the University of KwaZulu-Natal to accomplish the following objectives: (1) to inaugurate an ongoing system of institutional appraisal for the purpose of yearly reporting, (2) to support the yearly staff evaluation process which informs the equitable allocation of scarce resources to different academic units, and (3) to aid the institutional audit process of the university.

The study of Chen et al. (2006) focused on the application of the Balanced Scorecard to design an effective evaluation system in order to improve the performance of Chin-Min Institute of Technology (CMIT). Umashankar and Dutta (2007) recommended a Balanced Scorecard model which can be implemented in all higher education institutions and programs in India. Papenhausen and Einstein (2006) also outlined an all-inclusive and content-specific Balanced Scorecard for a business school. The results indicated that the implementation of a strategic management system requires active participation of every individual within the organization. Thus, every employee of the College should understand the strategy and apply it in the day-to-day activities in ways that contribute to the accomplishment of the strategy. Education and effective communication are critical factors in achieving these initiatives.

The study of Philbin (2011) identified how the management of universities can be improved through the adoption of an integrated performance measurement system based on the Balanced Scorecard. The study revealed specific benefits that arise from the operational use of the scorecard within the Institute which include the provision of specific information such as research and teaching capability. This information contributed to quality decision making concerning the training courses to be introduced and developed in the future.

Schobel and Scholey (2012) demonstrated the application of the Balanced Scorecard in a higher education distance learning setting and underscored the value of financial strategies for higher education at an era when many universities are concentrated on performance system of measurement linked with learning. The study showed that Higher education institutions with clear financial policies that are closely tied to educational outcomes will be uniquely positioned for success even when their funding models change.

Sim and Koh (2001) compared the Balanced Scorecard with the traditional performance measurement practices and the effect of both methods on firm performance. The findings indicated that there is a positive influence of the Balanced Scorecard and performance measurement system combined with objectives and strategies in improving firm performance. Strohhecker 
(2007) investigated the effect of Balanced Scorecard on firm performance and the findings of the study revealed that the use of Balanced Scorecard shows a positive influence on organization performance. Wati and Triwiyono (2018) did a research on the relationship of Balanced Scorecard dimensions on firm performance and competitive advantage in Indonesia. The findings revealed that Balanced Scorecard is positively related to competitive advantage and organization performance.

Even though the application of the BSC in the corporate world is well documented, scant research has been reported concerning the application of the BSC in the field of education. In this paper, the effects of using the Balanced Scorecard as a performance measurement tool in accredited public universities in Ghana is empirically tested.

\section{Research Hypotheses}

The following set of hypotheses were used based on the survey problem and research objectives.

H1: The Financial Perspective of the Balanced Scorecard has a positive relation on the Perceived Strategic Performance of Accredited Public Universities in Ghana.

H2: The Internal Business Processes Perspective of the Balanced Scorecard has a positive relation on the Perceived Strategic Performance of Accredited Public Universities in Ghana.

H3: The Organizational Capacity Perspective of the Balanced Scorecard has a positive relation on the Perceived Strategic Performance of Accredited Public Universities in Ghana.

H4: The Customer Perspective of the Balanced Scorecard has a positive relation on the Perceived Strategic Performance of Accredited Public Universities in Ghana. 


\section{Figure 1}

Conceptual Framework

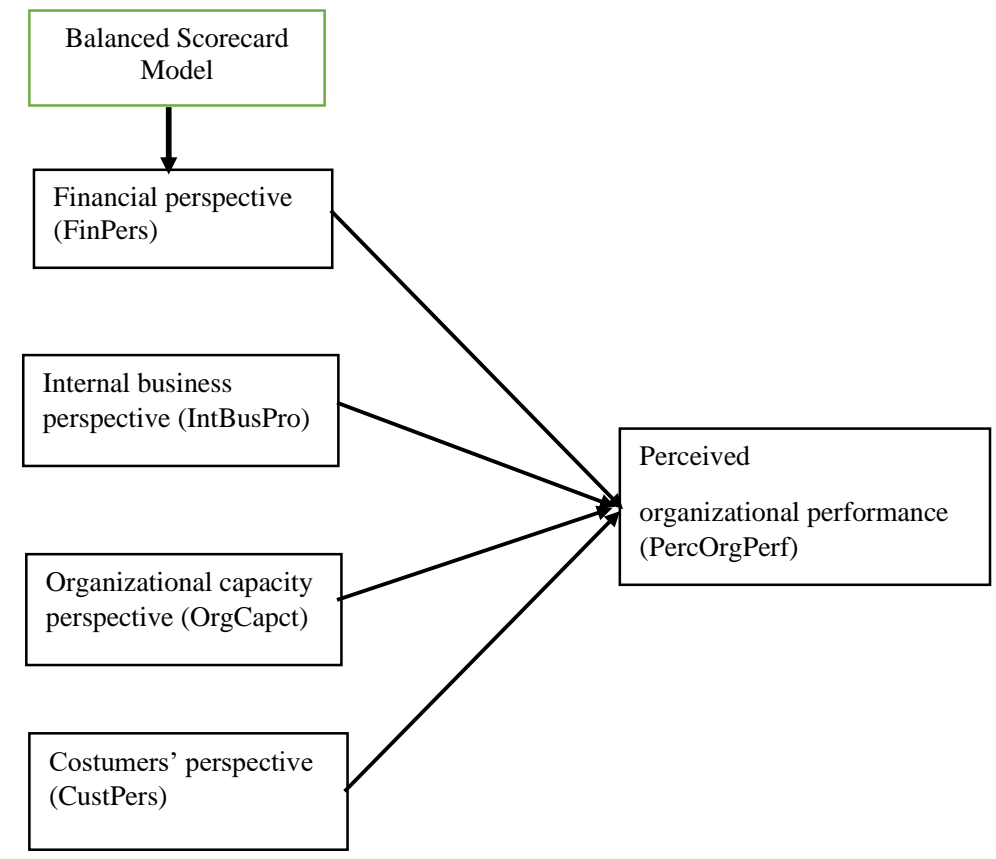

\section{Methodology}

In the past, important academic literature in educational research applied Kaplan and Norton's (1992) Balanced Scorecard (Beard, 2009; Cullen et al., 2003; Taylor \& Baines, 2012; Wu et al., 2011) to examine the performance management in higher education institutions (Camilleri \& Camilleri, 2018). Thus, the contribution of this study adds value to the existing literature as it examines the appraisal and performance management system of Ghanaian public universities from the African context.

This section of the study consists of the methodology, sampling techniques, the instruments, and data collection tool, which is utilized in the research to explore the link of the Balanced Scorecard constituents to the strategic performance of public universities in Ghana. The research adopted a cross-sectional, descriptive survey design (the positivist paradigm) to address the objective nature of the research goals (Bell et al., 2018). Since the present study has a practical and objective perspective, the quantitative methodology was considered the most appropriate approach to accomplish the objectives of the study (Bell \& Bryman, 2007; Bell et al., 2018). The objective was to show 
the usefulness of the Balanced Scorecard as a performance management tool for the assessment of public universities in Ghana. Structural equation model (SEM) was utilized with SmartPLS to analyze the data collected. SEM is a comprehensive statistical method that is used to test hypotheses about relations among observed and latent variables (Hair et al., 2019). In this study, the goal was to understand the patterns of correlation/covariance among a set of variables of the BSC and organizational performance.

The relevant population for the study consisted of all public traditional universities in Ghana. According to the National Accreditation Board (NAB) of Ghana, the total number of accredited public universities in Ghana is ten (10). Thus, this study is a census survey of all public universities in Ghana. Although there are public technical universities in Ghana, there were excluded because they have been recently upgraded to the status of a university. Data were obtained from the universities staff, i.e., both academic and administrative personnel.

Table 3 shows the list of names of these universities.

Table 3. Accredited Public Universities in Ghana (Traditional)

\begin{tabular}{|l|l|l|l|l|}
\hline No. & Institution & Nickname & Founded & Location \\
\hline $\mathbf{1}$ & University of Ghana & LEGON & 1948 & $\begin{array}{l}\text { Accra, Greater } \\
\text { Accra }\end{array}$ \\
\hline $\mathbf{2}$ & $\begin{array}{l}\text { Kwame Nkrumah University of } \\
\text { Science and Technology }\end{array}$ & KNUST & 1952 & Kumasi, Ashanti \\
\hline $\mathbf{3}$ & University of Cape Coast & $\begin{array}{l}\text { CAPE } \\
\text { VARS }\end{array}$ & 1961 & $\begin{array}{l}\text { Cape Coast, } \\
\text { Central }\end{array}$ \\
\hline $\mathbf{4}$ & University of Winneba, Winneba & UEW & 1992 & Winneba, Central \\
\hline $\mathbf{5}$ & University for Development Studies & UDS & 1992 & Tamale, Northern \\
\hline $\mathbf{6}$ & University for Professional Studies & UPS & 1965 & $\begin{array}{l}\text { Accra, Greater } \\
\text { Accra }\end{array}$ \\
\hline $\mathbf{7}$ & University of Mines and Technology & UMAT & 2001 & Tarkwa, Western \\
\hline $\mathbf{8}$ & $\begin{array}{l}\text { University of Health and Allied } \\
\text { Sciences }\end{array}$ & AHAS & 2011 & Ho, Volta \\
\hline $\mathbf{9}$ & $\begin{array}{l}\text { University of Energy and Natural } \\
\text { Resources }\end{array}$ & UENR & 2012 & $\begin{array}{l}\text { Sunyani, Brong } \\
\text { Ahafo }\end{array}$ \\
\hline $\mathbf{1 0}$ & $\begin{array}{l}\text { Ghana Institute of Management and } \\
\text { Public Administration }\end{array}$ & GIMPA & 1961 & $\begin{array}{l}\text { Achimota, } \\
\text { Greater Accra }\end{array}$ \\
\hline
\end{tabular}

Source: National Accreditation Board, Ghana

\section{Data Collection and Analysis}

The data collection instrument is one of the most comprehensive and fundamental parts of any scientific research. The research instrument was divided into three main parts: the demographics, which captures the profile information of respondents including the nature of work, educational qualification, and experience level. The Balanced Scorecard measures four 
aspects namely, financial, internal business process, organizational capacity, and customer or stakeholder perspective. The strategic performance explains core elements of organizational performance such as growth, monitoring, and control. Integrated with the research paradigm, the survey adopted the closedended, structured questionnaire to ensure the impartial responses of respondents or study participants. It was a five-point Likert scale spanning from strongly disagree to strongly agree, which was valued as 1-5: 1 signifying "the least" and 5 signifying "the highest". The survey instrument was adapted from the research documented by Baird and Su (2018) and M'maiti (2014). Items of the questionnaire were adapted based on the context and the result of the discussion with experts. The outcome was a pilot study involving fifty respondents. This pilot study was carried out to ensure the suitability and applicability of the survey instrument. The study then applied the Kaiservarimax rotation from principal component analysis together with a confirmatory factor analysis. This was done to eliminate any tenuous variables and to maintain key drivers (Pallant, 2005). Furthermore, the reliability test was also carried out to confirm the trustworthiness of the survey instrument. All Cronbach's alpha values were greater than 0.70, which signifies satisfactory internal consistency (Yang, 2005).

\section{Research Findings and Discussion}

The study administered questionnaires to 182 employees (Deans, Heads of Departments, Faculty members, Administrative Staff) from the 10 accredited public universities in Ghana. The demographic information of respondents was as follows:

Table 4. Demographic Information of Respondents

\begin{tabular}{llll}
\hline Variables & $\begin{array}{l}\text { Demographic } \\
\text { characteristics }\end{array}$ & Frequency & Percent \\
\hline \multirow{3}{*}{ Study sample } & Academic & 95 & 70.9 \\
& Administrative & 39 & 29.1 \\
& Total & 134 & 100.0 \\
Education level & PhD & 64 & 47.8 \\
& Master & 44 & 32.8 \\
& Bachelor & 26 & 19.4 \\
& Total & 134 & 100.0 \\
Experience & Below 10 years & 25 & 18.7 \\
& 10-20 years & 47 & 35.1 \\
& Above 20 years & 62 & 46.3 \\
& Total & $\mathbf{1 3 4}$ & $\mathbf{1 0 0 . 0}$ \\
\hline
\end{tabular}

However, responses were received from 147 respondents, which represents a response rate of 81 percent. Thirteen (13) questionnaires were excluded from the statistical analysis since these questionnaires had incomplete data on the study variables. Thus, there was a total of 134 usable 
questionnaires. This gave an effective response rate of seventy-four percent; (74\%). This is considered representative and satisfactory to draw valid conclusions for the research.

The reliability values are indicated in Table 5. Cronbach's Alpha (internal reliability) co-efficient was obtained for each of the study variables to ensure the trustworthiness of the research output. Tavakol and Dennick (2011) stated that Cronbach's Alpha spans from 0.70 to 0.95 , even though there are diverse reports regarding its acceptability. For this current study, the values of the Cronbach's alpha ranges from 0.827 and 0.884 , which are good enough (satisfactory) values.

Table 5. Reliability of Constructs

\begin{tabular}{llll}
\hline Constructs & $\begin{array}{l}\text { Cronbach's } \\
\text { Alpha }\end{array}$ & $\begin{array}{l}\text { Composite } \\
\text { Reliability }\end{array}$ & $\begin{array}{l}\text { Average Variance Extracted } \\
\text { (AVE) }\end{array}$ \\
\hline FinPers & $; 0.827$ & 0.892 & 0.636 \\
IntBusPro & 0.875 & 0.910 & 0.670 \\
OrgCapct & 0.798 & 0.861 & 0.555 \\
CustPers & 0.884 & 0.912 & 0.632 \\
PercOrgPerf & 0.867 & 0.908 & 0.637 \\
\hline
\end{tabular}

Consequently, the acceptable value of convergent validity (CR) is above 0.70 , while the acceptable value of the average variance extracted (AVE) is 0.50 or above (Hair et al., 2017; Hair et al., 2019; Hair et al., 2018). From the table above, the minimum value of the composite reliability is 0.861 . This value is more than the normal or standard value. The minimum value of the AVE in the current study is 0.555 , which is more than the minimum standard value of 0.50 . Thus, both the average variance extracted and composite reliability values are up to standard.

\section{Discriminant Validity}

Discriminant validity is suitable for assessing the measure error. It is usually applied to correct the attenuation which helps to determine whether the concepts are related. The study employed the Heterotrait-monotrait ratio of correlations (HTMT) to measure the discriminant validity. Hair et al. (2019) defined Heterotrait-monotrait ratio as "the mean value of the item correlations across constructs that is relative to the geometric mean of the average correlations for the items measuring the same construct" (p.9). Discriminant validity issues arise when the HTMT values are high. Henseler et al. (2015) recommended a threshold value of 0.85 when the constructs are conceptually well-defined. According to Hair, Risher et al (2019), the heterotrait-monotrait ratio of correlations should be less than 0.85 to confirm the discriminant validity. The results of the heterotrait-monotrait values are captured in Table 6 below. All the values are less than 0.85 . 
Table 6. Discriminant Reliability

\begin{tabular}{|l|l|l|l|l|l|}
\hline & FinPers & IntBusPro & OrgCapct & CustPers & PercOrgPerf \\
\hline Fonstructs & & & & & \\
\hline IntBusPro & 0.797 & & & & \\
\hline OrgCapct & 0.710 & 0.819 & & & \\
\hline CustPers & 0.821 & 0.412 & 0.745 & & \\
\hline PercOrgPerf & 0.723 & 0.563 & 0.523 & 0.795 & 0.798 \\
\hline
\end{tabular}

\section{Confirmatory Factor Analysis}

The results of the confirmatory factor analysis are presented in Tables 7-11. The acceptance rule is that all the items must be less than or equal to $0.50(\leq 0.50)$. Thus, all the output numbers had gone beyond the accepted value. After a thorough examination, factors such as PercOrgPerf1, OrgCapct6, and FinPers1 were omitted since $20 \%$ of total items can be deleted (Henseler et al., 2015). Furthermore, the factor loading in Table 6 shows that within the financial perspective variable, item FinPers 3 is the highest (0.912) while item FinPers6 is the lowest (0.806) among the values. The IntBusPro has values ranging from 0.885 to 0.745 (Table 8). Also, the OrgCapct values of the factor loading are between 0.849 and 0.556 for OrgCapct 1 and OrgCapct5, respectively (Table 9). On the other hand, CustPers has the highest value of 0.838 and the lowest value of 0.756 (Table 10). The path model is shown in Figure 2 below.

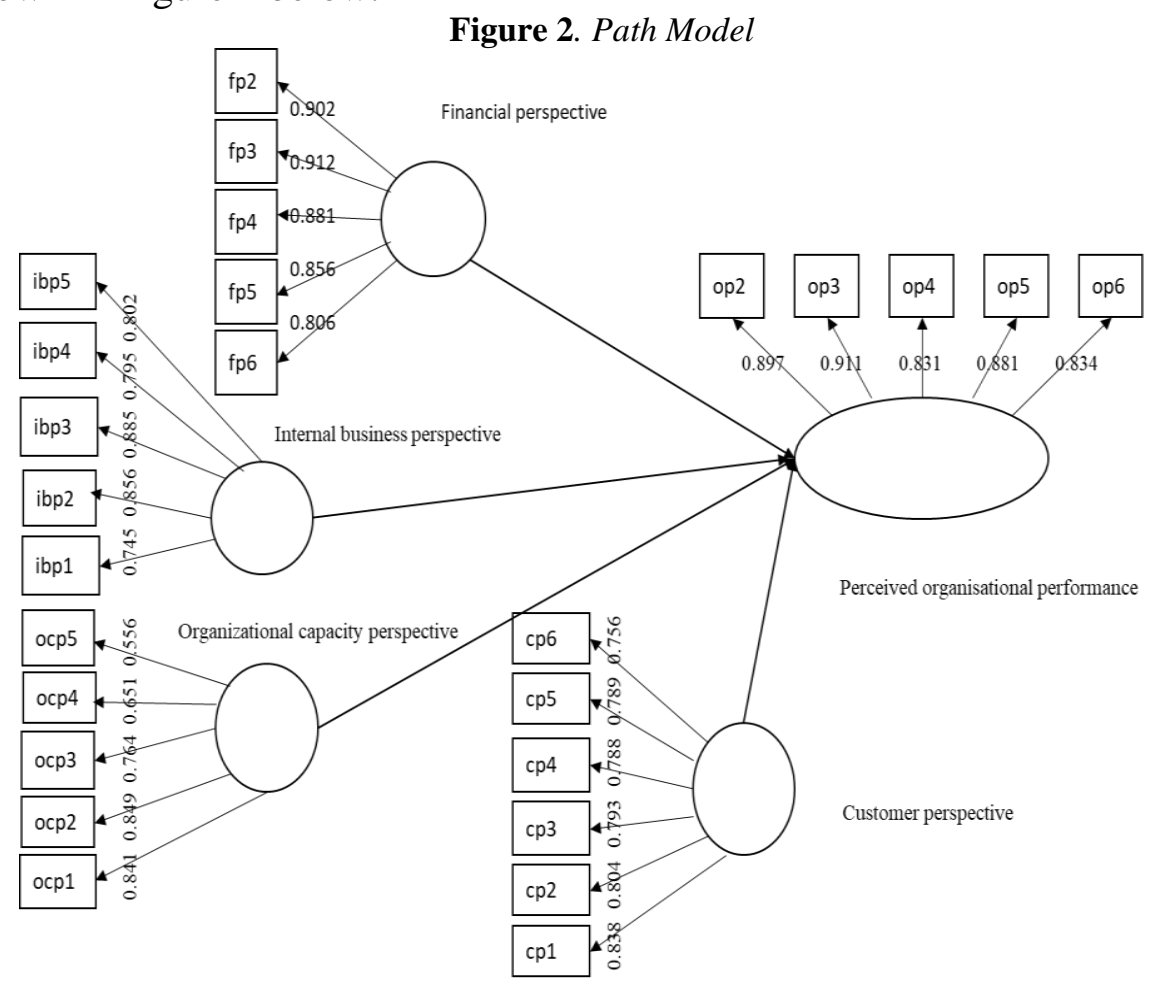


Table 7

\begin{tabular}{|c|c|}
\hline Items & Financial Perspective \\
\hline FinPers2 & 0.902 \\
\hline FinPers3 & 0.912 \\
\hline FinPers4 & 0.881 \\
\hline FinPers5 & 0.856 \\
\hline FinPers6 & 0.806 \\
\hline
\end{tabular}

Table 8

\begin{tabular}{|c|c|}
\hline Items & Internal Business Processes \\
\hline IntBusPro1 & 0.745 \\
\hline IntBusPro2 & 0.856 \\
\hline IntBusPro3 & 0.885 \\
\hline IntBusPro4 & 0.795 \\
\hline IntBusPro5 & 0.802 \\
\hline
\end{tabular}

Table 9

\begin{tabular}{|c|c|}
\hline Items & Organizational Capacity Perspective \\
\hline OogCapct1 & 0.841 \\
\hline OrgCapct2 & 0.849 \\
\hline OrgCapct3 & 0.764 \\
\hline OrgCapct4 & 0.651 \\
\hline OrgCapct5 & 0.556 \\
\hline
\end{tabular}

Table 10

\begin{tabular}{|c|c|}
\hline Items & Customers' Perspective \\
\hline CustPers1 & 0.838 \\
\hline CustPers2 & 0.804 \\
\hline CustPers3 & 0.793 \\
\hline CustPers4 & 0.788 \\
\hline CustPers5 & 0.789 \\
\hline CustPers6 & 0.756 \\
\hline
\end{tabular}

Table 11

\begin{tabular}{|c|c|}
\hline Items & Perceived Organizational Performance \\
\hline PercOrgPerf2 & 0.897 \\
\hline PercOrgPerf3 & 0.911 \\
\hline PercOrgPerf4 & 0.831 \\
\hline PercOrgPerf5 & 0.881 \\
\hline PercOrgPerf6 & 0.834 \\
\hline
\end{tabular}


However, in the perceived organizational performance variable, the factor loading ranges from 0.911 and 0.831 for the highest and lowest values, respectively (Table 10). The rationale behind the test runs was to ensure that the unrelated constructs are removed in order to ensure the reliability of the dataset. Consequently, managers and organizational leaders can depend on the research results as they engage in the decision-making processes.

\section{Path Coefficient}

To investigate the likely relationship between the statistical variables in the structural equation modelling, the study verified the path coefficient weights. The results of the bootstrapping method for the structural model are illustrated in Table 12 below.

Table 12. Bootstrapping Results (direct effects)

\begin{tabular}{|c|c|c|c|c|c|}
\hline $\begin{array}{c}\text { Hypot } \\
\text { hesis }\end{array}$ & Relationship & $\begin{array}{c}\text { Standard } \\
\text { Deviation } \\
(\text { STDEV) }\end{array}$ & $\begin{array}{c}\text { T Statistics } \\
(|\mathbf{o} / \mathbf{S T D E V}|)\end{array}$ & $\begin{array}{c}\text { p- } \\
\text { Values }\end{array}$ & Decision \\
\hline H1 & FinPers $\rightarrow$ PercOrgPerf & 0.167 & 4.381 & 0.000 & Accepted \\
\hline H2 & IntBusPro $\rightarrow$ PercOrgPerf & 0.096 & 3.213 & 0.032 & Accepted \\
\hline H3 & OrgCapct $\rightarrow$ PercOrgPerf & 0.076 & 4.375 & 0.000 & Accepted \\
\hline H4 & CustPers $\rightarrow$ PercOrgPerf & 0.204 & 3.461 & 0.034 & Accepted \\
\hline
\end{tabular}

At $5 \%$ significant level (t-value $\geq 1.96$ )

The $t$-values establishing relationships between the constructs are as follows: FinPers $\rightarrow$ PercOrgPerf $(\mathrm{t}=4.381)$, IntBusPro $\rightarrow$ PercOrgPerf $(\mathrm{t}=$ 3.213), OrgCapct $\rightarrow$ PercOrgPerf $(t=4.375)$, and CustPers $\rightarrow$ PercOrgPerf $(t=$ 3.461 ), which were found to have significant relationships.

Hypothesis 1 based on the test results is accepted. It shows the link between the financial perspective and the perceived organizational performance since the $\mathrm{p}$-value is $<0.05$. This means that the financial perspective of the Balanced Scorecard has a positive influence on the perceived organizational performance. The remaining three hypotheses $(\mathrm{H} 2$, H3, and H4) were all accepted. To be specific, all the four Balanced Scorecard perspectives have a statistically significant positive effect on perceived organizational performance. The results of this study are in line with the results of earlier studies carried out by Sim and Koh (2001), Strohhecker (2007), and Wati and Triwiyono (2013). Correspondingly, their studies generated the same findings that BSC positively influences or impacts organization performance.

In addition, the results are important for the administrators of the ten public universities in Ghana. This will help to set a clear direction of their institutions as regards the application of the Balanced Scorecard's ideas in their various universities.

Figure 3 shows the picture of a Balanced Scorecard with each of its perspective providing a framework through which the strategic performance 
within a public higher education environment can be seen. The study assumed that the four constituents of the Balanced Scorecard must align with the vision, mission, and strategic goals of the universities to allow the administrators/leadership monitor and review their strategies appropriately (Camilleri \& Camilleri, 2018). Therefore, it helped to form the culture of evidence.

\section{Figure 3}

\section{Balanced Scorecard Model}

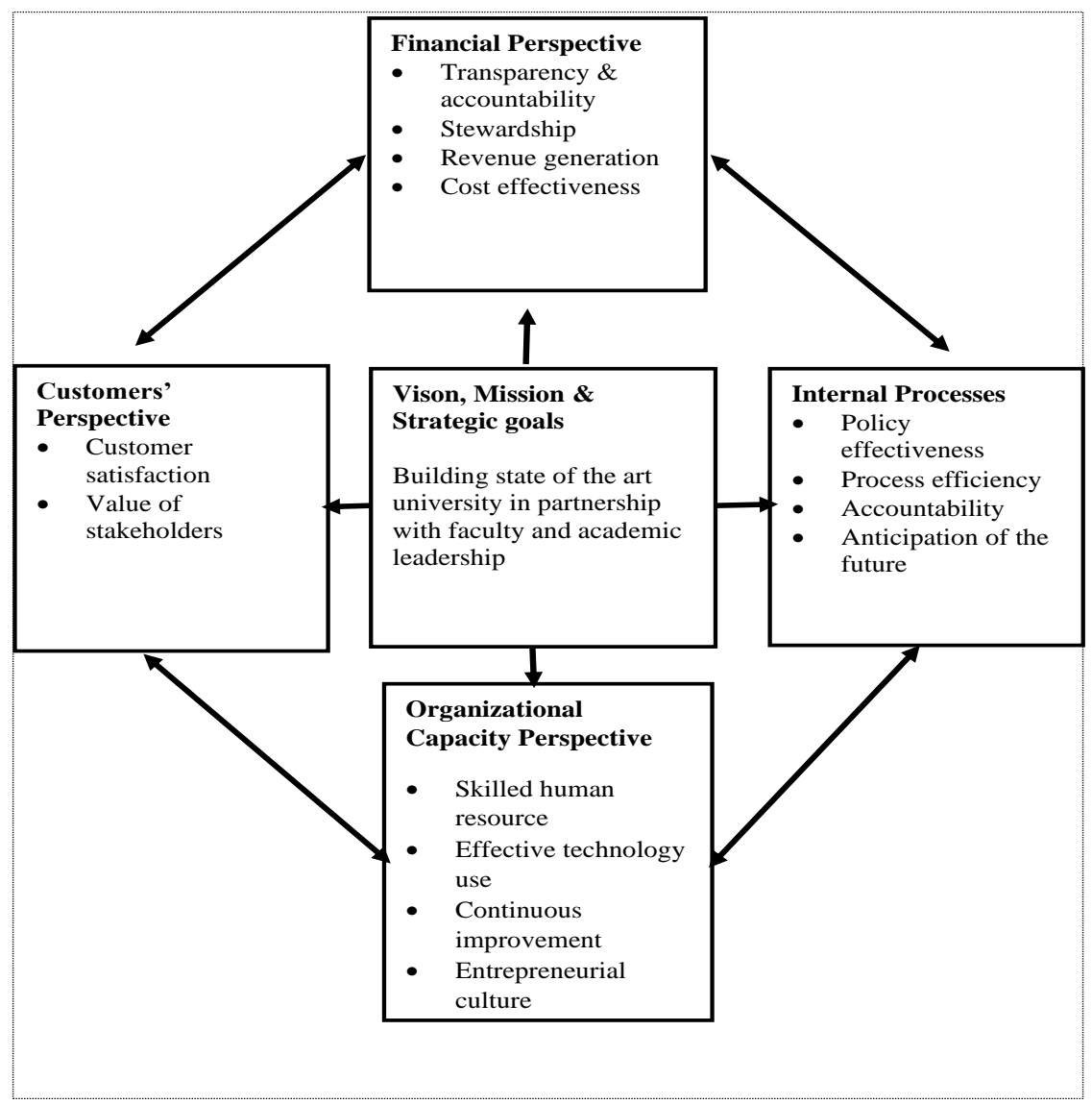

\section{Discussion}

It is clear from the results of the research that there is a statistically significant positive relationship between performance management systems and higher education institutions' performance. The results have revealed that 
non-financial metrics have greater implications for employees' effective functioning in their core activities. This is so because the performance management metrics empower employees to be more responsible within their primary work domain. Subsequently, the outcomes of this study aligns with the findings of Kaplan and Norton (2004). It is therefore recommended to highlight the application of non-financial metrics alongside the financial measures to effect improvements within the internal business processes. This will in turn build a great teaching and learning environment. For instance, the success of execution of the objectives to deliver innovative and high-quality academic curricula and optimize the utilization of the universities' scarce resources can be assessed through some key performance metrics such as the number of learning opportunities, satisfaction of students towards the university's facilities, as well as the student's/teacher occupancy ratio. The results of this research also underscore organizational capacity that should be engaged as a part of repetitive and everyday exercise rather than seen as a random activity.

This study suggests that the Balanced Scorecard aids the leadership and management of Ghanaian public universities to pay attention to the financial and non-financial measures. The broad measures of the Balanced Scorecard enable university management to consider other areas of the performance of academic staff. Specifically, the financial perspective of the Balanced Scorecard includes robustness of the budgeting procedures, transparency of the financial administration system, an analysis of past financial performance, and fairness in the allocation of resources and funds (Camilleri \& Camilleri, 2017; Geuna \& Martin, 2003). The internal business perspective is focused on the performance of all the employees of the university, both teaching and non-teaching staff, in relation to evaluating their primary mandates. For the teaching staff, the measurement is focused on research output, teaching, and rendering service to the community in quantifiable measures (for instance, the number of manuscripts published in high-impact research journals). More so, lecturers and professors can be evaluated through several ways such as attendance and contribution in national and international conferences related to their area of specialization, contribution to local and national debates on developmental matters, participation in professional development programs, and so on. The organizational capacity component is linked to life-long learning and innovation. According to some scholars, organizational capacity entails the intellectual competences, skills development, and capabilities (Brown, 2012; Lassoued, 2018). This component of the Balanced Scorecard scans the functioning of universities based on availability and quality of infrastructure, technology transfer, quality human resources, and other resources that are required for knowledge construction and dispersal. The customer's 
perspective specifically appraises the universities strategic performance based on faculty members, students and their parents, sponsors, and the Ghanaian society overall.

Furthermore, this study reviewed literature on the stakeholder theory. However, while listening to some of the participants during the survey, several points were raised which bordered on the concepts of institutional theory (DiMaggio \& Power, 1983). This provides a broadening of the application of institutional theory, which gives details to some of the motivations behind certain performance management practices adopted by universities. For instance, there is a presence of political influence and the crisis of legitimacy, professionalization, and standard responses to uncertainty in the public universities in Ghana (Simpson \& Aboagye-Otchere, 2014). In the future, research could be conducted to explore in depth whether the interrelationship between institutional factors and organizational leaders' interests affect the implementation of performance management systems in universities. This is because power relations between the different stakeholder groups faced by an organisation could have a considerable impact on the side of performance indicators employed.

\section{Conclusion}

Basically, this research was carried out to investigate the link between the four perspectives of the Balanced Scorecard and how it influences organizational performance within the context of Ghanaian accredited public universities. Based on the findings, it can be concluded that there is a positive and significant influence of the four Balanced Scorecard dimensions to universities performance. Nevertheless, it is important to bear in mind that the exploration of the relationship between the four perspectives of the Balanced Scorecard and the strategic organizational performance was solely on perceived basis. The operationalization and measurement did not take into consideration the different levels of the organizational hierarchy such as lower, middle, and upper levels. This was one of the constraints of the study. Therefore, it should be a caution on the part of policy makers to make allowances for this limitation during the time of decision-making.

Applying the Balanced Scorecard as a strategic management tool in the education sector is quite new in Ghana and in the African continent. There is scant research reported concerning the Balanced Scorecard usage in higher education institutions (Abdulai, 2016; Karathanos \& Karathanos, 2005; Pereira \& Melao, 2012). There appears to be well-recorded empirical studies in the business sector than in the field of education. Thus, this study has enriched the existing empirical literature on the application of the Balance Scorecard in the domain of higher education. 
Also, the study's contribution has included a critical review of the literature where it related the increased introduction of managerialism in private and public higher education institutions. This phenomenon has unsurprisingly led to an intensified reliance on suitable performance management and appraisal of academic members of staff. Therefore, the researcher relied on four perspectives of the Balanced Scorecard to survey the academic staffs' experiences of the strategic performance appraisal process in the traditional university setting.

\section{The Way Forward}

The Balanced Scorecard has a great capacity to create value in higher education institutions. It is a strategic performance management tool that can empower universities and higher education institutions to clarify their missions and visions. Its balanced viewpoints can enhance the performance of universities since it ascertains what genuinely matters to students (customers) and other stakeholders. The Balanced Scorecard evaluates both the past and present performance. Also, its non-financial performance indicators, its objectives, and targets are wide-ranging and across the board as they provide realistic guidance for the future.

The key-performance indicators of the Balanced Scorecard as well as their incorporation into the strategic planning of universities are projected to enrich the quality and ranking of universities regarding the following: (a) the provision of student-centric education, (b) enhancing the universities research impact, and (c) fostering and intensifying outreach with stakeholders, among other goals. Inevitably, the universities' achievements in the above areas could give rise to significant advances in global rankings. Consequently, Ghanaian public universities will be able to attract more students and highly productive academia.

\section{Suggestion for Future Research}

As a way forward, there are several future research possibilities. First, there is room for further research to observe how universities make use of the Balanced Scorecard performance management tool. Currently, the Balanced Scorecard tool is not mature in the Ghanaian context. A limitation of this study was associated with methodological element. Although the research design demonstrated universal applicability and objective reality, there is still room to investigate the phenomenon subjectively. Therefore, future research works can employ qualitative methodologies and other survey designs in different settings. There is also room to carry out longitudinal studies to explore how the Balanced Scorecard and its performance system of measurements contribute towards high quality education for the sustainability and improvement of public universities. According to Simons (2000), a 
performance management system cannot be successfully planned and used without considering the important element of human behaviour. Hence, it would be intriguing to do a study to find out how the attitude of employees affect the use and effectiveness of the Balanced Scorecard. Finally, this study proposes to carry out a comparative investigation between the application of the Balanced Scorecard in public and private higher education institutions to highlight the peculiarities between the two institutional arrangements.

\section{References:}

1. Abdulai, M. (2016). Performance management practices of universities in Ghana: An evaluation based on the balanced scorecard. M.Phil. Thesis. University of Ghana.

2. Aktas, C. B. (2015). Reflections on interdisciplinary sustainability research with undergraduate students. International Journal of Sustainability in Higher Education, 16(3), 354-366. https://doi.org/10.1108/IJSHE-11-2013-0153

3. Al-Zwyalif, I.M. (2012). The possibility on implementing Balanced Scorecard in Jordanian private universities. International Business Research, 5(11), 113-120.

4. Arnesen, A.L. \& Lundahl, L. (2006). Still social and democratic? Inclusive education policies in the Nordic welfare states. Scandinavian Journal of Educational Research, 50(3), 285-300. https://doi.org/10.1080/00313830600743316.

5. Ayris, P., Lopez de San Roman, A., Maes, K., \& Labastida, I. (2018). Open science and its role in universities: A roadmap for cultural change. League of European Research Universities (LERU).

6. Baird, K. \& Su, S. (2018). The association between controls, performance measures and performance. International Journal of Productivity and Performance Management, 67 (6), 967-984. https://doi.org/10.1108/ijppm-03-2017-0059

7. Balanced Scorecard Collaborative Inc (2002). Using the balanced scorecard to build a strategy-focused healthcare organization. http://azflexprogram.publichealth.arizona.edu/Docs/PowerPoint/Kate O'Brien.ppt.

8. Barnes, G. (2007). A balanced scorecard for higher education institutions: Moving towards business performance management. http://www.ukznstats.ukzn.ac.za

9. Baxter, J. A. (2017). School Governor regulation in England's changing education landscape. Educational Management Administration and Leadership, 45(1), 20-39. https://doi.org/10.1177/1741143215587306 
10. Beard, D.F. (2009). Successful applications of the balanced scorecard in higher education. Journal of Education for Business, 84(5), 275282. https://doi.org/10.3200/JOEB.84.5.275-282

11. Bell, E., Bryman, A., \& Harley, B. (2018). Business research methods. Oxford University Press.

12. Bell, E. \& Bryman, A. (2007). The ethics of management research: An exploratory content analysis. British Academy of Management, 18(1), 63-77. https://doi.org/10.1111/j.1467-8551.2006.00487.x

13. Billing, D. (2004). International comparisons and trends in external quality assurance of higher education: Commonality or diversity? Higher Education, 47(1), 113-137. https://www.jstor.org/stable/4151559

14. Bititci, U., Mendibil, K., Nudurupati, S., Turner, T., \& Garengo, P. (2004). The interplay between performance measurement, organizational culture, and management styles. In Neely, A., Kennerly, M., and Walters, A. (eds.), Performance Measurement and Management: Public and Private, Centre for Business Performance, Cranfield University, Cranfield, pp. 107-114.

15. Bleiklie, I. (2001). Towards European convergence of higher education policy? Higher Education Management, 13(3), 9-29.

16. Brancato, C.K. (1995). New corporate performance measures. New York: The Conference Board.

17. Brewer, P.D. \& Brewer, K. L. (2010). Knowledge management, human resource management, and higher education: A theoretical model. Journal of Education for Business, 85(6): 330-335. https://doi.org/10.1080/08832321003604938

18. Bridoux, F. \& Stoelhorst, J. (2016). Stakeholder relationships and social welfare: A behavioral theory of contributions to joint value creation. Academy of Management Review, 41(2), 229-251. https://doi.org/10.5465/amr.2013.0475

19. Brown, C. (2012). Application of the balanced scorecard in higher education: opportunities and challenges: an evaluation of balance scorecard implementation at the College of St. Scholastica. Planning for Higher Education, 40 (4), 40-50.

20. Camilleri, M.A. (2020). Using the balanced scorecard as a performance management tool in higher education. Management in Education. Forthcoming. https://doi.org/10.1177/0892020620921412

21. Camilleri, M. A. (2019a). Measuring the corporate managers' attitudes toward ISO's social responsibility standard. Total Quality Management \& Business Excellence , 30(13-14), 1549-1561. https://doi.org/10.1080/14783363.2017.1413344 
22. Camilleri, M. A. (2019b). Higher Education Marketing: Opportunities and Challenges in the Digital Era. Academia, O(16-17), 4-28. DOI:10.26220/aca.3169

23. Camilleri, M. A. \& Camilleri, A. C. (2019). The students' readiness to engage with mobile learning apps. Interactive Technology and Smart Education, 17(1), 28-38. DOI: 10.1108/ITSE-06-2019-0027

24. Cappiello, G. \& Pedrini, G. (2017). The performance evaluation of corporate universities. Tertiary Education and Management, 23(3), 304-317. https://doi.org/10.1080/13583883.2017.1329452

25. Cardoso, S., Tavares, O., \& Sin, C. (2015). The quality of teaching staff: Higher education institutions' compliance with the European Standards and Guidelines for Quality Assurance - the case of Portugal. Educational Assessment, Evaluation and Accountability, 27(3), 205222. https://doi.org/10.1007/s11092-015-9211-z.

26. Caruth, G.D. \& Caruth, D.L. (2013). Understanding resistance to change: A challenge for universities. Turkish Online Journal of Distance Education, 14(2), 12-21.

27. Cederblom, D. (1982). The performance appraisal interview: A review, implications, and suggestions. Academy of Management Review, 7(2), 219-227. https://doi.org/10.1108/eb028267

28. Chen, S-H., Yang, C-C., \& Shiau, J-Y. (2006). Scorecard in the performance evaluation of higher education. The TQM Magazine, 18 (2), 190-205.

29. Chou, C.P. \& Chan, C.F. (2016). Trends in publication in the race for world-class university: The case of Taiwan. Higher Education Policy, 29(4), 431-449. DOI:10.1057/s41307-016-0016-6

30. Cullen, J., Joyce, J., Hassall, T., \& Broadbent, M. (2003). Quality in higher education: From monitoring to management. Quality Assurance in Education, 11(1), 5-14. DOI: 10.1108/09684880310462038

31. Davis, S. \& Albright, T. (2004). An investigation of the effect of balanced scorecard implementation on financial performance. Management Accounting Research, 15 (2), 135-153. https://doi.org/10.1016/j.mar.2003.11.001

32. Deem, R., Mok, K. H., \& Lucas, L. (2008). Transforming higher education in whose image? Exploring the concept of the 'world-class' university in Europe and Asia. Higher Education Policy, 21(1): 83-97. DOI:10.1057/palgrave.hep.8300179

33. Deming, W.E. (1993). The new economics. Cambridge, MA: MIT Center of Advanced Engineering Study.

34. DiMaggio, P. \& Powell, W. W. (1983). The iron cage revisited: Collective rationality and institutional isomorphism in organisational 
fields. American Sociological Review, 48(2), 147-160. http://www.jstor.org/stable/2095101

35. DeNisi, A. \& Smith, C.E. (2014). Performance appraisal, performance management, and firm-level performance: a review, a proposed model, and new directions for future research. Academy of Management Annals, $8(1)$

127-179. https://doi.org/10.5465/19416520.2014.873178

36. de Waal, A.A. (2006). The role of behavioral factors and national cultures in creating effective performance management systems. Systemic Practice and Action Research, 19(1), 61-71. DOI: 10.1007/s11213-005-9004-2

37. del Sordo, C., Orelli, R.L., Padovani, E., \& Gardini, S. (2012). Assessing global performance in universities: an application of balanced scorecard. Social and Behavioral Sciences, 46, 4793 - 4797. https://doi.org/10.1016/j.sbspro.2012.06.336

38. Dill, D.D. (1997). Higher education markets and public policy. Higher Education Policy, 10(3-4), 167-185. DOI:10.1007/s10734-004-17468

39. Dill, D.D. \& Soo, M. (2005). Academic quality, league tables, and public policy: A cross-national analysis of university ranking systems. Higher Education, 49(4), 495-533.

40. Dilts, D.A., Haber, L.J., Bialik, D., \& Haber, L.J. (1994). Assessing What Professors Do: An Introduction to Academic Performance Appraisal in Higher Education (Vol. 61). Westport (CT). USA: Greenwood Publishing Group.

41. Eccles, R.G. (1991). The performance management manifesto. Harvard Business School.

42. Epstein, M. J., Rejc, A., \& Slapnicar, S. (2004). The impact of performance measurement on corporate financial performance. In Neely, A., Kennerly, M., and Walters, A. (eds.), Performance Measurement and Management: Public and Private, Centre for Business Performance, Cranfield University, Cranfield, pp. 339-346.

43. European Commission (2018). New Commission guidance supports EU Member States in transition to Open Science. https://ec.europa.eu/info/news/new-commission-guidance-supportseu-member-states-transition-open-science-2018- apr-25_en.

44. Fadeeva, Z. \& Mochizuki, Y. (2010). Higher education for today and tomorrow: university appraisal for diversity, innovation and change towards sustainable development. Sustainability Science, 5(2): 249256. DOI:10.1007/s11625-010-0106-0

45. Farid, D. \& Mirfakhredini, H. (2008). Balanced scorecard application in universities and higher education institutes: Implementation guide 
in an Iranian context. Annals of University of Bucharest, Economic and Administrative Series, 31-45. http://annalseas.faa.ro/en/article/Balanced-Sc

46. Figge, F., Hahn, T., Schaltegger, S., \& Wagner, M. (2002). The sustainability balanced scorecard-linking sustainability management to business strategy. Business Strategy and The Environment, 11(5), 269-284. https://doi.org/10.1002/bse.339

47. Fijatkowska, J. \& Oliveira, C. (2018). Balanced Scorecard in universities. Journal of Intercultural Management, 10(4), 57-83. DOI:10.2478/joim-2018-0025.

48. Franco, M. \& Bourne, M. (2003). Factors That Play a Role in 'Managing Through Measures, Centre for Business Performance, Cranfield School of Management, Cranfield University, Cranfield.

49. Freeman, R. E. (1984). Strategic management: A stakeholder approach. Pitman Publishing Company.

50. Freeman, R. E., Harrison, J.S., \& Zyglidopoulos, S.C. (2018). Stakeholder theory: Concepts and strategies. Cambridge: Cambridge University Press.

51. Geuna, A. \& Martin, B.R. (2003). University research evaluation and funding: An international comparison. Minerva, 41(4), 277-304. https://www.jstor.org/stable/41821253

52. Hair, J. F., Hult, G. T. M., Ringle, C. M., \& Sarstedt, M. (2017). A primer on partial least squares structural equation modelling (PLSSEM).( 2nd ed.). Sage.

53. Hair, J.F., Risher, J.J., Sarstedt, M., \& Ringle, C.M. (2019). When to use and how to report the results of PLS-SEM. European Business Review, 31(1), 2-24. https://doi.org/10.1108/EBR-11-2018-0203

54. Hair, J. F., Sarstedt, M., Ringle, C. M., \& Gudergan, S. P. (2018). Advanced issues in partial least squares structural equation modelling (PLS-SEM). Sage.

55. Harrison, J.S., Barney, J.B., Freeman, R.E., \& Phillips, R.A. (eds.). (2019). The Cambridge handbook of stakeholder theory. Cambridge University Press.

56. Harrison, J. S. \& Wicks, A. C.( 2013). Stakeholder theory, value, and firm performance. Business Ethics Quarterly, 23 (1), 97-124. DOI: 10.5840/beq20132314

57. Henseler, J., Ringle, C.M., \& Sarstedt, M.A. (2015). A new criterion for assessing discriminant validity in variance-based structural equation modelling. Journal of the Academy of Marketing Science, 43 (1), 115-135. DOI 10.1007/s11747-014-0403-8 
58. Hood, C. (1995). The 'new public management' in the 1980s: variations on a theme. Accounting, Organizations and Society, 20: $93-$ 109.

59. Holloway, J., Lewis, J., \& Mallory, G. (eds.) (1995). Performance Measurement and Evaluation. Sage.

60. Imai, M. (1986). Kaizen: The key to Japan's competitive success. Random House.

61. Jauhiainen, A., Jauhiainen, A., Laiho, A., \& Lehto, R. (2015). Fabrications, time-consuming bureaucracy, and moral dilemmas: Finnish University employees' experiences on the Governance of University Work. Higher Education Policy, 28(3), 393-410. DOI: http://dx.doi.org/10.1057/hep.2014.18

62. Kaplan, R.S. \& Norton, D.P. (1992). The balanced scorecard measures that drive performance. Harvard Business Review, 70.

63. Kaplan, R.S. \& Norton, D.P. (2000). The strategy-focused organization, how balanced scorecard companies thrive in the new business environment. Harvard Business School Press.

64. Kaplan, R.S. \& Norton, D.P. (2001).Transforming the Balanced Scorecard from Performance Measurement to Strategic Management: Part I. Accounting Horizon , 15(1), 87-104. https://doi.org/10.2308/acch.2001.15.1.87

65. Kaplan, R.S. \& Norton, D.P. (2004). The strategy map: Guide to aligning intangible assets. Strategy and Leadership, 32 (5), 10-17. https://doi.org/10.1108/10878570410699825

66. Kaplan, R.S., Davenport, T.H., Robert, N.P.D.K.S., Kaplan, R.S., \& Norton, D.P. (2001). The strategy-focused Organization: How balanced scorecard companies thrive in the new business environment, Harvard Business Press.

67. Karathanos, D. \& Karathanos, P. (2005). Applying the Balanced Scorecard to Education. The Journal of Education for Business, 80(4), 222-230. DOI:10.3200/JOEB.80.4.222-230

68. Kassahun, T. (2010). Rethinking institutional excellence in Ethiopia: Adapting the Balanced Scorecard (BSC) model. Journal of Business and Administrative Studies, 2(1), 22-53. DOI: 10.4314/jbas.v2i1.63517

69. Kiriri, P.N. (2018). Management of performance in Higher Education Institutions: The application of the Balanced Scorecard (BSC). European Journal of Education, 1(3), 168-176.

70. Kohoutek, J., Veiga, A., Rosa, M.J., \& Sarrico, C.S. (2018). The European Standards and Guidelines for Quality Assurance in the European Higher Education Area in Portugal and the Czech Republic: 
Between the Worlds of Neglect and Dead Letters? Higher Education Policy, 31(2), 1-24. DOI: 10.1057/s41307-017-0050-z

71. Lassoued, K. (2018). Balanced Scorecard implementation in higher education: An Emirati perspective. Corporate Ownership \& Control, 15(3), 205-216. DOI:10.22495/cocv15i3c1p5

72. Lawrence, J.J. \& McCullough, M.A. (2001). A conceptual framework for guaranteeing higher education. Quality Assurance in Education, 9(3), 139-52.

73. Lo, W.Y.W. (2009). Reflections on internationalisation of higher education in Taiwan: perspectives and prospects. Higher Education, 58(6), 733-745. DOI: 10.1007/s 10734-009-9209-x

74. Lo, W.Y.W. (2011). Soft power, university rankings and knowledge production: Distinctions between hegemony and self-determination in higher education. Comparative Education, 47(2), 209-222. https://doi.org/10.1080/03050068.2011.554092

75. Lo, W.Y.W. (2014). Dimension 1: Influences of University Rankings: Changes in Policy, University Governance, and Individual Behaviours. In University Rankings. Heidelberg: Springer, pp. 81-101.

76. Lucianetti, L. (2010). The impact of the strategy maps on balanced scorecard performance. International Journal of Business Performance Management, 12(1), 21-36. http://www.inderscience.com/link.php?id=36040

77. Marr, B. (2004). Business Performance Management: Current State of the Art. Cranfield School of Management, Cranfield University and Hyperion.

78. Marginson, S. (2013). The impossibility of capitalist markets in higher education. Journal of Education Policy, 28(3), 353-370. https://doi.org/10.1080/02680939.2012.747109

79. Mitchell, R. K., Agle, B. R., \& Wood, D. J. (1997). Toward a theory of stakeholder identification and salience: Defining the principle of who and what really counts. Academy of Management Review, 22 (4), 853 - 886. DOI:10.5465/amr.1997.9711022105

80. M'maitti, H.I. (2014). The Balanced Scorecard as a strategic management tool in the Kenyan commercial state corporations. Master Thesis, University of Nairobi, Kenya.

81. National Accreditation Board of Ghana (2020). Public University.http://www.nab.gov.gh/institution_name.php?info=Public $\% 20$ University

82. National Council for Tertiary Education (2018). Annual Report. http://www.nab.gov.gh/about-us/vision-and-mission.

83. Nathan, M.L. (2010). 'Lighting tomorrow with today': Towards a (strategic) sustainability revolution. International Journal of 
Sustainable Strategic Management, 2(1), 29-40. DOI: 10.1504/IJSSM.2010.032162

84. Ofori, D. \& Atiogbe, E. (2012). Strategic planning in public universities: A developing country perspective. Journal of Management and Strategy, 3(1), 67-82. DOI: https://doi.org/10.5430/jms.v3n1p67

85. Papenhausen, C. \& Einstein, W. (2006). Insights from the Balanced Scorecard Implementing the Balanced Scorecard at a college of business. Measuring Business Excellence, 10 (3), 15-22.

86. Pallant, J. (2005). SPSS survival guide. Crow's Nest. Allen \& Unwin, Australia.

87. Pearce, J. (2003). Social enterprise in any town. London: Calouste Gulbenkian Foundation.

88. Pereira, M.M. \& Melao, N. (2012). The implementation of the balanced scorecard in a school district: Lessons learned from an action research study. International Journal of Productivity and Performance Management, 61(8), 919-939. DOI: 10.1108/17410401211277156.

89. Pettigrew, A. M. (1990). Longitudinal Field Research: Theory and Practice. Organization Science, 1(3), 267-292. http://pubsonline.informs.org/doi/abs/10.1287/orsc.1.3.267

90. Philbin, S.P. (2001). Design and implementation of the Balanced Scorecard at a university institute. Measuring Business Excellence, 15(3), 34-45. https://doi.org/10.1108/13683041111161148

91. Pollitt, C. \& Bouckaert, G. (2017). Public Management Reform A Comparative Analysis - Into the Age of Austerity ( $4^{\text {th }}$ edn). Oxford University Press.

92. Pollitt, C. \& Bouckaert, G. (2004). Public Management Reform: A Comparative Analysis (2nd edn.). Oxford University Press.

93. QS Rankings (2019). World University Rankings Methodology. https://www.topuniversities.com/qs-world-universityrankings/methodology

94. Ruben, B.D. (1999). Toward a balanced Scorecard for Higher Education: Rethinking the college and university excellence indicators framework. QCI, Center for Organizational Development and Leadership, Rutgers, The State University of New Jersey, 99-02. http://www.qci.rutgers.edu

95. Saunders, M., Mann, R., \& Smith, R. (2008). Implementing Strategic initiatives: A framework of leading practices. International Journal of Operations \& Production Management, 28 (11), 1095-1123. DOI: 10.1108/01443570810910908. 
96. Schobel, K.B. \& Scholey, C. (2012). Balanced scorecards in education: Focusing on financial strategies. Measuring Business Excellence, 16(3),17-28. DOI:10.1108/13683041211257385

97. Sim, K. L. \& Koh, H. C. (2001). Balanced Scorecard: A rising trend in strategic performance, Measurement. Measuring Business Excellence, 5(2), 18-27. DOI:10.1108/13683040110397248

98. Simpson, S. N. Y. \& Aboagye-Otchere, F. (2014). Understanding the use of balanced scorecard in the context of State-owned enterprises in developing countries: A case from Ghana. Research Journal of Finance and Accounting, 13(5), 123- 132.

99. Smeenk, S., Teelken, C., Eisinga, R., \& Doorewaard, H. (2008). An international comparison of the effects of HRM practices and organizational commitment on quality of job performances among European university employees. Higher Education Policy, 21(3), 323344. https://doi.org/10.1057/hep.2008.12

100. Stewart, A.C. \& Carpenter-Hubin, J. (2000). The Balanced Scorecard beyond reports and rankings. Planning for Higher Education, 29(2), 37-42.

101. Storey, A. (2010). Performance management in Schools: Could the Balanced Scorecard help? School Leadership and Management, 22 (3), 321-338. https://doi.org/10.1080/1363243022000020435.

102. Strohhecker, J. (2007). Does a Balanced Scorecard Management Cockpit Increase Strategy Implementation Performance? Findings of a series of experiments using a system dynamics based micro-world. 25th International Conference of the System Dynamics Society

103. Tavakol, M. \& Dennick, R. (2011). Making sense of Cronbach's alpha. International Journal of Medical Education, 2, 5355. DOI: 10.5116/ijme.4dfb.8dfd.

104. Taylor, J. \& Baines, C. (2012). Performance management in UK universities: implementing the Balanced Scorecard. Journal of Higher Education Policy and Management, 34 (2), 111- 124. https://doi.org/10.1080/1360080X.2012.662737.

105. THE (2019). The Times Higher Education World University Rankings explained.

https://www.timeshighereducation.com/student/advice/worlduniversity-rankings-explained

106. Thompson, J. (1967). Organizations in Action. McGraw Hill.

107. Umashankar, V. \& Dutta, K. (2007). Balanced scorecards in managing higher education institutions: an Indian perspective. International Journal of Educational Management, 21(1), 54-67. http://dx.doi.org/10.2139/ssrn.1615304. 
108. Waal, D. \& André, A. (2006). The role of behavioral factors and National cultures in creating effective performance management Systems. Systemic Practice and Action Research, 19(1). DOI: 10.1007/s11213-005-9004-2

109. Waring, M. (2013). All in this together? HRM and the individualisation of the academic worker. Higher Education Policy, 26(3), 397-419. https://doi.org/10.1057/hep.2013.7

110. Wati, L.N. \& Triwiyono, G. (2018). The Effect of using Balanced Scorecard on competitive advantage and its impact on firm performance. Journal of Applied Accounting and Finance, 2(1): 1-17. DOI:10.33021/jaaf.v2i1.306

111. Williams, W.M. \& Ceci, J.J. (1997). How'm I doing? Problems with student ratings of instructors and courses. Change, Sept-Oct., 1223.

112. Wood, P. \& Salt, J. (2018). Staffing UK universities at international campuses. Higher Education Policy, 31(2), 181-199. https://doi.org/10.1177/1028315313483773

113. Wu, H.Y., Lin, Y.K., \& Chang, C.H. (2011). Performance evaluation of extension education centers in universities based on the balanced scorecard. Evaluation and Program Planning, 34(1), 37-50. https://doi.org/10.1016/j.evalprogplan.2010.06.001

114. Yang, B. (2005). Factor analysis methods. In Research in Organizations: Foundations and methods of inquiry. Berrett-Koehler, pp.181-199. 